\title{
The Labor Market Effects of Foreign-owned Firms*
}

\author{
Rita Almeida \\ DECRG \\ The World Bank
}

April 21, 2004

\begin{abstract}
Foreign firms often have a more educated workforce and pay higher wages than domestic firms. This does not necessarily imply that foreign ownership translates into higher demand for educated workers or higher wages, since foreign investment may be guided by unobservable firm characteristics correlated with the demand for educated workers or wages. I examine foreign acquisitions of domestic firms and find small changes in the workforce skill composition and wages following acquisition. Foreign investors "cherry pick" domestic firms that are already very similar to the group of existing foreign firms.
\end{abstract}

Keywords: foreign direct investment, acquisitions, employment, wage structure and panel data.

JEL Classification codes: C31, F23 and J31.

${ }^{*}$ I am specially grateful to Antonio Ciccone for raising my interest in the topic and for his guidance and to Pedro Carneiro for several comments. I am also grateful to the Portuguese Ministry of Employment's Department of Statistics for access to the data and, in particular, to Ermelinda Lopes and Artur Simões for their help. I also thank Bruno Cassiman, Mário Centeno, Koen Debacker, Jaume Garcia, Maia Güell, Sergi Jimenez, Adriana Kugler and José Mata for several suggestions. I benefited from comments made by participants at the $7^{\text {th }}$ meeting of the Portuguese Economic Society, Universitat Pompeu Fabra, XXVII Simposio de Analisis Economico(Salamanca), Universidade Nova de Lisboa, CEPR conference on "Globalization and labor markets" (Bergen) and at the DECRG, World Bank. I gratefully acknowledge the financial support of Fundação para a Ciência e Tecnologia. The findings expressed in this paper are those of the author and do not necessarily represent the views of the World Bank. Address: 1818 H Street, NW, MSN MC3-301, Washington, DC 20433, USA. E-mail: ralmeida@worldbank.org 


\section{Introduction}

Regions and countries compete for foreign investment because it is perceived to have several benefits for the host economy (Caves, 1996). For example, foreign firms often are associated with better technology, which may spill over to domestic firms ${ }^{1}$. Moreover, their jobs are perceived to be good in the sense that they require more qualifications, offer more training or pay higher wages. These reasons have been used to justify regional or national industrial policy in order to secure foreign investment.

Existing empirical work comparing foreign and domestic firms has shown that foreign firms have a more educated workforce and pay higher wages than domestic firms. But these findings may at least in part be driven by selection of foreign investment into certain firms or sectors. For example, consider the finding that foreign ownership is associated with higher wages. This may be driven by wages increasing after the foreign acquisition, or by foreigners buying domestic firms that pay above-average wages. In this paper, I use panel data on Portuguese firms to provide evidence on the type of domestic firms bought by foreigners and on the effect of foreign acquisitions on skill composition and wages. I find that foreigners "cherry pick" domestic firms, choosing those firms with an educated workforce and higher wages. Moreover, these firms are already very similar to the group of existing foreign firms. Following the foreign acquisition, I find no significant changes in the educational composition of the workforce. There is evidence that average wages increase following the foreign acquisition but changes are smaller than cross-sectional estimates of this differential.

The positive wage premium for foreign firms is a stylized fact for developed and developing countries. Feliciano and Lipsey (1999), using industry-level data for the US for the period 1987-1992, find a differential in favor of foreign firms that is larger for services (9-10 percent) than for manufacturing (5-7 percent). For UK manufacturing establishments, Girma et al. (1999) find that foreign firms pay, on average, about 5 percent higher wages than domestic firms, even when sector, establishment size and productivity are controlled for. For Mexico

\footnotetext{
${ }^{1}$ For example, Dimelis and Louri (2001), Haskel et al.(2002) and Aitken et al.(1996) find evidence consistent with positive spillovers to the host economy.
} 
and Venezuela, Aitken et al. (1996), also find higher wages for foreign firms. With competitive labor markets, there is no reason for a positive foreign wage premium unless workers or firms differ in some unobservable characteristics. In most of the firm level data sets used in the empirical literature, worker level information such as education, experience and tenure of the workforce is not collected. The assumption in this work is that omitting these characteristics does not generate significant biases in the estimation of the differences between domestic and foreign firms. Lipsey and Sjoholm (2003) control for the worker's education and other worker level characteristics but they still find a foreign wage premium in a cross section of Indonesian firms. Conyon et al. (2002) and Lipsey and Sjoholm (2002) try to overcome the problem of the unobservable firm characteristics that are correlated to the firm nationality by analyzing the impact on average wages of a foreign acquisition. Conyon et al. (2002) find that average wages increase by 3.4 percent following a foreign acquisition but they do not control for any workforce characteristics. Lipsey and Sjoholm (2002) find that average wages of blue and white collar workers increase by 10 percent and 21percent respectively. Both find evidence that part of the cross section wage premium in manufacturing is due to a causal effect of foreign investment on wages. An alternative explanation for the foreign wage premium is based on imperfect labor markets. For example, if foreigners incur in higher search costs they may pay more to workers in order to discourage turnover. If foreign firms offer more training, have less power with unions or are more likely to adhere to minimum wages, they may also pay higher wages. Moreover, foreigners could pay higher wages simply because they have higher profitability than domestic firms (rent sharing theories ${ }^{2}$ ).

In this paper I analyze the Portuguese case which combines two important features. First, Portugal had a permissive legal framework for the operation of foreign firms that translated into generous amounts of foreign direct investment (FDI) in the late 1980s and $1990 \mathrm{~s}^{3}$. Before becoming an European Union member in 1986, the amount of FDI in Portugal never

\footnotetext{
${ }^{2}$ Rent sharing theories argue that the labor market is not competitive as empirically wages are correlated with measures of the firm or industry "ability to pay". See e.g. Blanchflower et al. (1996) for evidence on the US manufacturing.

${ }^{3}$ The importance of European Union and OECD as sources of FDI is clear: in 1992, 76\% of the FDI came from the EU and $89 \%$ from OECD countries.
} 
reached 1 percent of GDP (3.2 percent of total investment); in the early 1990s it tripled to 3.2 percent (12 percent of total investment in 1990). Second, a comprehensive firm level data set covering the 1990s is available. In particular, the firm and its foreign participation can be traced over time, making this data particularly suited for the analysis of FDI on labor demand and wages ${ }^{4}$.

One of the relevant topics in the policy debate is the impact of FDI on labor markets and, in particular, on employment and wages of the different educational groups. Mata and Portugal (2002) document that, in Portugal during the 1980s, foreign start-ups and foreign acquisitions $^{5}$ had a more educated labor force than domestic start-ups. They also find that foreign start-ups and foreign acquisitions pay, on average, higher wages than domestic startups. However, one of the reasons for this finding might be the educational level of workers in the new foreign and domestic firms ${ }^{6}$. The most important difference between their work and my paper is that I am interested in identifying the effect of foreign acquisitions on labor demand and wages. Moreover, I am also interested in identifying how firms acquired by foreigners differ from the typical domestic firm.

Using data for the period 1991-1998, I start by analyzing differences in workforce educational composition and wage structure between foreign and domestic firms, without making any distinction between foreign acquisitions and existing foreign firms. A large part of the differences are explained by the sector and regional composition of foreign firms and, to a lower extent, by other firm and worker characteristics usually unaccounted for due to lack of data. But even after controlling for these characteristics, significant differences remain in wages and workforce characteristics of domestic and foreign firms. For example, in manufacturing, foreign firms have a proportion of low educated workers 7 percentage points lower than domestic firms and pay 15 percent higher wages, even after controlling for regional and

\footnotetext{
${ }^{4}$ Abowd et al. (1999) use a matched employer-employee data set for France, very similar to the data used in this paper. They find that firm effects, while important, are not as important as unobservable individual effects in explaining wage variation.

${ }^{5}$ Foreigners may start operating in a country by two different ways: greenfield entry (start-ups) or acquisition of an ongoing firm.

${ }^{6}$ Machado and Mata (1998) using data for Portugal, between 1982 and 1994, found also that foreign firms pay higher wages and that this premium was larger for higher wages.
} 
sector composition as well as size and age of the firm.

The data set I use allows me to identify the group of firms that switch from domestic to foreign ownership during the 1990s. Therefore, I make two contributions to the literature on the effects of foreign firms on the labor market. First, comparing outcomes before and after foreign acquisitions one can control for firm unobserved heterogeneity since it seems likely that some of the unobservable characteristics of the firm do not change over time and can be captured in a fixed effect. Second, comparing the group of acquired firms with the typical domestic firm in the pre-acquisition period, I can assess the extent to which firms acquired by foreigners differ from the typical domestic firm.

One of my main findings is that there exists an important selection effect as foreigners "cherry pick" domestic firms with a more educated workforce. For example, looking at manufacturing firms that were acquired by foreigners between 1993 and 1996, I find that, two years before the acquisition, they have a proportion of low educated workers 9 percentage points lower than that of domestic firms in the same sector of activity and pay higher wages to all education groups (differentials range from 17 percent for the low educated to 39 percent to the high educated workers). In fact, domestic firms that were acquired between 1993 and 1996, already looked very similar to existing foreign firms in workforce composition and wage structure. I also find that there are no significant changes in the firm's workforce composition following a foreign acquisition. Wages increase for most of the education groups after the acquisition, even though this increase is smaller than in cross-sectional comparisons of domestic and foreign firms.

The plan of the paper is as follows. In the next section, I describe the data used and present some descriptive statistics. Section 3 explains the econometric methodology, presents and discusses the results on workforce composition. Section 4 and discusses the results on wage structure. Section 5 concludes. 


\section{Data}

The data set used is a survey conducted every year by the Portuguese Ministry of Employment, "Quadros do Pessoal". It is a longitudinal data file matching firms and workers. The data is based on a questionnaire that every firm with wage-earners operating in Portugal is legally obliged to fill out ${ }^{7}$. Records are available at the firm and plant level, and have a detailed description of the labor force characteristics ${ }^{8}$.

Among other firm characteristics, the share of equity owned by non-residents is reported. Therefore, for every firm I am able to identify whether the foreign investment is (1) an acquisition of an existing domestic firm, (2) a fully owned subsidiary or (3) a minority or majority holding. I use a 10 percent threshold of foreign participation to classify a firm as foreign and also to identify ownership changes ${ }^{9}$. Evidence in panel 5 of Table A1 in the Appendix shows that the choice of a 10 percent threshold is not too restrictive. In manufacturing, more than half of the foreign acquisitions have the full control of the firm, while foreign firms prefer majority stakes. In non-manufacturing, the foreign participation, in both foreign and acquired firms, is preferentially one of full control. At the worker level, I use information on the education level, sex, age, tenure and hours worked. This information is then aggregated, by education groups, at the firm level. The three education groups used are: low (up to 6 years of schooling), medium (high school and technical courses) and high (bachelor and college degrees). Gross monthly wages are computed summing up monthly earnings as well as other regular and irregular payments. Hourly wages are gross wages divided by total monthly hours worked (including overtime). Firm average wages are computed excluding the extreme values for hourly wages ${ }^{10}$. Throughout the paper I use

\footnotetext{
${ }^{7}$ Public Administration is not included.

${ }^{8}$ The survey has information for an average of 180,199 firms and of 2,248,076 employees per year, during 1991-1998.

${ }^{9}$ Ownership is related to those who make decisions about resources, but the relevant concept for policy purposes is that of control. Measuring control is difficult and, even if a firm acquires more than 50\% of the shares of another, it may choose not to exercise its controlling rights. On the other hand, even without majority an owner may have the effective control (McGuckin, 2001, discusses this issue).

${ }^{10}$ Workers with implausibly low earnings (hourly wage lower than $50 \%$ of the minimum wage) or implausibly high earnings (irregular payments -like dismissal payments- exceeding twice the other monthly wage components) were excluded from the sample. There were few of these cases.
} 
hourly real wages per employee to control for differences between foreign and domestic in the hours worked ${ }^{11}$. The consumer price index comes from National Department of Statistics. The level of aggregation used for region and sector composition was Nuts1-region ${ }^{12}$ and three digits sector classification ${ }^{13}$.

The selection of firms that were acquired by foreigners is done according to the following criteria. First, I identified all the firms that have operated for two consecutive years with 100 percent domestic capital and that for the next three years have at least 10 percent of foreign capital. Therefore, while these firms are newly foreign, they existed before under domestic ownership. Second, I restrict the analysis to firms that operated for at least five consecutive years. If the analysis is to be based on the change in ownership, it is important to have information on the firm two years before the acquisition in order to analyze the firm's choices before the ownership change, while the use of the following two years ensure that the firm does not exit immediately after. Even though the sample period for identifying foreign acquisitions is 1993-1996, it stretches to 1991-1998, due to these requirements. Third, the sample is restricted to firms with more than 30 employees in every surveyed year. Fourth, the firm must be located in continental Portugal and cannot operate in the primary sector in any surveyed year ${ }^{14}$. The selection of firms that remain always under domestic and foreign ownership was as similar as possible to the sample of acquisitions. First, they must operate for at least five consecutive years. Second, during that period a domestic firm can never be foreign participated and foreign firms have always at least 10 percent of foreign ownership.

\footnotetext{
${ }^{11}$ Workers of foreign owned firms work on avearge less hours than workers in domestic firms. E.g., low educated workers in foreign firms work 171 hours per month (173 hours in domestic firms) and high educated workers work 166 hours (168 hours in domestic firms).

${ }^{12}$ Eurostat divides the european countries into Nuts (Nomenclature of Territorial Units for Statistics). These can vary between Nut 1 to Nut 3, according to the disagregation level. The Nut 1 classification divides Portugal into 5 regions: North, Center, Lisbon Area, Alentejo and Algarve.

${ }^{13}$ Because the national sector classification changed in 1994, I assumed that, between 1991 and 1995, there is no change in sector classification at three digit level by using the firm sector classification in 1995 .

${ }^{14}$ The usual problem of the non-random exit of acquisitions from the sample (attrition) does not seem to be severe in this data. Mata and Portugal (2002) find evidence that the survival rates for acquired firms are very high. After five years of operation more than two thirds and more than four fifths of the foreign greenfield and acquisition entrants are still in operation. This is not the case for the UK, where Girma and Görg (2001) find that foreign acquisitions reduce the probability of survival of the plant in the electronics industry.
} 
Third, they must have at least 30 employees in every sampled year. Fourth, they must be located in continental Portugal and cannot operate in the primary sector ${ }^{15}$. The final sample is an unbalanced panel of 3,410 domestic firms, 194 foreign firms and 103 foreign acquisitions of domestic firms ${ }^{16}$. I have also identified a group of 37 domestic acquisitions of foreign firms (24 in manufacturing and 13 in non-manufacturing ${ }^{17}$ ). Due to the small number of these observations I focus the analysis on the group of foreign acquisitions ${ }^{18}$.

Table A1 in the Appendix characterizes the final sample in several dimensions. Panel 1.6 shows that sector composition of the foreign investment explains part of the wage differentials between foreign and domestic firms. The proportion of firms located in the top highest paid sectors are at least two times larger in foreign owned firms than in domestic firms. Therefore, a better measure of the differences in skill composition and wages between foreign and domestic firms must control for the fact that foreign firms tend to be concentrated in different sectors of activity. Let $p_{j s}^{k}$ be the share of education group $k$ in the total workforce of foreign firm $j$ operating in sector $s, p_{s}^{k}$ be the share of education group $k$ of domestic firms operating in sector $s, w_{j s}^{k}$ be the avearge hourly wage of education group $k$ in foreign firm $j$ and $w_{s}^{k}$ the average hourly wage of education group $k$ in domestic firms operating in sector $s$. Column (1) of Table 1 reports the average difference across all sectors for $p_{j s}^{k}-p_{s}^{k}$ and $\ln w_{j s}^{k}-\ln w_{s}^{k}$. The differences in employment are reported as the average across sectors of the $\frac{e m p_{j s}}{e m p_{s}}$, where $e m p_{j s}$ is the employment of the foreign firm $j$ operating in sector $s$ and $e m p_{s}$ is the average employment in the domestic firms of the sector. I compute the differences between firms operating in the same two-digit sector of activity. Panel A reports the results for manufacturing sectors and panel B for non-manufacturing sectors.

Column (1) compares foreign and domestic firms. In manufacturing, the share of low ed-

\footnotetext{
${ }^{15}$ The primary sector includes agriculture and mining. Firms operating in 3 digit sectors with exclusively domestic firms that fill in these requirements were excluded from the sample.

${ }^{16} 73 \%$ of the domestic firms in the sample and $58 \%$ of the foreign and acquired firms operate in manufacturing sectors. More than $90 \%$ of the firms in the sample are observed for more than six years. $1 \%$ of domestic firms are observed for less than five years because they have less than 30 workers in the worker's files during that year.

${ }^{17}$ There are only two firms that fill these requirements and that experienced more than one ownership change, i.e., a foreign and a domestic acquisition).

${ }^{18}$ However, at the end of each section I discuss the findings when this sample is also included.
} 
ucated workers is 9 percentage points lower than that of domestic firms, while the groups of medium and high educated workers have shares 7 percentage points and 3 percentage points, respectively, higher than those of domestic firms. In non-manufacturing, these differences are even greater with the share of low educated workers 25 percentage points below, and of medium and high educated workers 13 percentage points and 12 percentage points above that of domestic firms, respectively ${ }^{19}$. This evidence shows that foreign firms have a more educated workforce, both in manufacturing and non-manufacturing, and that these differences are quantitatively important. Also, foreign firms employ on average, 3.5 times and 2.2 times more employees than domestic firms in manufacturing and non-manufacturing, respectively. Given the differences in the educational composition, it is not surprising to find differences in the average wages among domestic and foreign firms. In manufacturing foreign firms pay wages 26 percent higher than domestic firms and in non-manufacturing 55 percent higher. Wage differences within education categories are also substantial. Also, the foreign wage premium increases with education. This finding is important, since it shows that the wage differential cannot be entirely explained by differences in the educational workforce composition nor by sector composition of foreign firms, even though region and sector location are important in explaining the wage differentials ${ }^{20}$.

Columns (2) and (3) in Table 1 compare acquired firms with domestic firms two years before and one year after the foreign acquisition, respectively. For example, firms in manufacturing two years before becoming foreign owned have, on average, a share of low educated workers 8 percentage points below that of domestic firms in the same sector. This difference increases to 10 percentage points one year after the acquisition. Differences in nonmanufacturing are even larger with the share of low educated workers 21 percentage points below that of domestic firms in the same sector. The magnitude of the wage differences is also large and quantitatively very similar to the ones in column (1). This shows that acquired domestic firms were already very different from the average domestic firm in the same sector

\footnotetext{
${ }^{19}$ Table A2 in the Appendix shows that manufacturing has a less educated workforce and pays, on average, lower wages than non-manufacturing. These wage differences prevail within education groups.

${ }^{20}$ These are unweighted means.
} 
of activity before the acquisition both in manufacturing and non-manufacturing. Therefore, acquired firms have a more educated workforce and pay higher wages than domestic firms to all the education groups ${ }^{21}$. The comparison of columns (2) and (3), shows the evolution following the foreign acquisition. Differences in the workforce educational composition increase both in manufacturing and in non-manufacturing. Also, acquired firms in manufacturing do not experience any change relative to the average wages of domestic firms, while in the non-manufacturing sector there is an increase in wages after the acquisition. Columns (4) and (5) present the comparisons between acquired and foreign firms two years before and one year after the foreign acquisition, respectively. Differences both in workforce composition and wages become much smaller and not statistically significant in manufacturing and non-manufacturing sectors ${ }^{22}$. Relative to foreign firms, acquired domestic firms are similar in size in manufacturing and are 50 percent larger in non-manufacturing.

Caves (1996) argues that foreign firms have a technological advantage over domestic firms, either generated by the ownership of some intangible assets (e.g. specific technological knowledge, a brand name or superior organizational capabilities) or by a privileged access to external capital markets. If this is the case, we would expect this advantage of foreign over domestic firms to translate into a higher demand for skilled workers on the one hand, and into higher productivity, and therefore higher wages on the other. Descriptive statistics in this section show that foreign firms have a more educated workforce and pay higher average wages. The wage premium is in part explained by the higher human capital of foreign firms but that is not all, as differences are still prevalent within each education category. Furthermore, firms that will become acquired in the following two years already have a more educated workforce and pay higher wages than domestic firms in the same sector of activity. During this period, they already look very similar to foreign firms. But, as seen in Table A1, foreign firms tend to be located in the Lisbon area where average wage are higher, and

\footnotetext{
${ }^{21}$ The hypothesis that acquired firms have lower shares of low educated workers and higher shares of medium and high educated workers cannot be rejected in columns (1) to (3). The hypothesis of a positive wage differential for all the education groups is also not rejected.

${ }^{22}$ The hypothesis that acquired firms do not differ from foreign firms in the workforce composition and wages paid is not rejected in columns (4) and (5).
} 
tend to be larger than domestic firms. Worker characteristics may also differ between foreign and domestic firms causing average wages to differ. I turn next to regression analysis where these and other firm and worker characteristics will be taken into account.

\section{Employment in Foreign Firms}

To analyze employment of skilled labor, I estimate the following model for the three education groups (low, medium and high):

$$
y_{k j t}=\beta_{k} f_{o r}+Z_{j t} \lambda_{k}+\alpha_{k t}+\alpha_{k r}+\alpha_{k s}+\epsilon_{k j t}
$$

$y_{k j t}$ is firm $j$ share of workers with education $k$ at time $t$. for ${ }_{j t}$ is a dummy variable if firm is foreign owned, therefore, at this stage I do not take into account if a domestic firm will become foreign owned latter on. $Z_{j t}$ is a vector of firm characteristics including both a set of dummy variables for the size of firm $j$ at time $t$ ( less than 49 workers, 50-99, 100-499, more than 500) and a set of dummy variables for the firm age (less than 5 years, 5-15, more than 15). Finally, $\alpha_{k t}, \alpha_{k r}$ and $\alpha_{k s}$ are time, region and sector dummy variables, respectively. The year dummies control for economy wide shocks that affect one education group similarly across all firms. Differences due to regional location of the firms are captured by $\alpha_{k r}$ and differences due to sector composition are captured by $\alpha_{k s}$. Because the impact of the explanatory variables on the three education groups has to sum up to zero, these restrictions are imposed in the $\operatorname{model}^{23}$ (e.g. $\beta_{\text {low }}+\beta_{\text {med }}+\beta_{\text {hig }}=0$ ). I estimate the three equations jointly as a system of seemingly unrelated equations. Table 2 presents the results for manufacturing ${ }^{24}$. Reported standard errors assume that disturbances are independently distributed across firms. Specification (1) reports the results of including only the variable $f_{0} r_{j t}$ in the model. Foreign firms have a less educated workforce (proportion of low educated workers 15 percentage points lower than in domestic firms). Including explanatory variables as sector, region, size and cohort decreases the coefficients of low and medium ed-

\footnotetext{
${ }^{23}$ This procedure is standard in the literature estimating demand equations since the shares of expenditure in different goods must sum up to one.

${ }^{24}$ Throughout the paper I report the results separately for manufacturing and non-manufacturing sectors. I never accept that the models are the same for the two groups.
} 
ucated workers in almost 50 percent: the share of medium and high educated workers are 5 percentage points and 2 percentage points above that in domestic firms, respectively ${ }^{25}$. Table 3 reports the same results for non-manufacturing. Again, part of the differences in the workforce composition between domestic and foreign firms are due to region, sector, size of the foreign firms. However, as reported in column (2) of these tables, even after controlling for these characteristics, the proportion of medium educated and high educated workers is 6 percentage points and 9 percentage points above that in domestic firms.

These cross-sectional findings may at least in part be driven by selection of foreign investment into certain firms or sectors with a more skilled workforce. Table A3 in the Appendix shows that at the time of the acquisition, foreigners may choose among domestic firms operating in the same two-digit sector with very different workforce compositions ${ }^{26}$. By estimating the same model within two-digit sectors of activity I rule out the second hypothesis of sector selection. Table A4 in the Appendix shows that foreign firms have a more educated workforce within almost all two-digit sectors ${ }^{27}$.

\subsection{The Sample of Foreign Acquisitions}

One way to control for the unobservable characteristics that might explain the differences between foreign and domestic firms is by comparing the period before and after the acquisition for those firms that are acquired by foreigners. This sample, by construction, controls for part of the unobserved firm heterogeneity since it is the same firm changing ownership, and several things remain constant before and after the acquisition. For example, with information on acquisitions it is possible to know whether foreigners increase the demand for education or if they buy firms with the closest structure possible to theirs. To disentangle these effects, the following model is estimated for the sample of acquisitions and foreign

\footnotetext{
${ }^{25}$ To allow for differentiated impacts on the labor market outcomes according to the percentage of foreign capital, I estimate the same model with minority, majority and full foreign ownership dummies. Foreign firms have a more educated workforce for all groups and results are not statistically different between majority and full ownership.

${ }^{26}$ Table A3 in the Apendix computes the means and standard deviations for the proportions of high educated workers within each sector of activity for the domestic firms in the sample. The heterogeneity in the workforce composition also holds within a regions and sectors of activity.

${ }^{27}$ Sectors where the differences between foreign and domestic firms are highest include the wholesale and retail trade, transport and communication as well as real estate (all non-manufacturing sectors).
} 
owned firms:

$$
y_{k j t}=\eta_{k j}+\beta f_{o r} r_{k j}+Z_{k j t} \lambda_{k}+\alpha_{k t}+\alpha_{k r}+\alpha_{k s}+\epsilon_{k j t}
$$

where for $_{j t}$ is a dummy variable if firm $j$ is foreign owned. The fixed effect, $\eta_{k j}$, summarizes the impact of permanent differences in observed and unobserved characteristics affecting the outcome $y_{k j t}$. The remaining variables have the same notation as above ${ }^{28}$. Finally, the error term, $\epsilon_{k j t}$, is assumed to be uncorrelated across firms and time. The parameters in equation (3.2) are estimated, including the fixed effects, by least squares. Thus, no matter how the firm's permanent characteristics are related to the acquisition, the estimates of this effect are unbiased.

This estimation approach generalizes the differences in differences technique. The need for including another group of firms in the regression is made clear in Meyer (1994). Comparing an outcome before and after the acquisition is not sufficient because it could also be affected by other factors that are contemporaneous with the acquisition. Assuming that shocks contemporaneous to the acquisition affect acquired firms and control firms in the same way, the coefficient on the foreign ownership variable would be an unbiased estimator of the impact of ownership change. The main problem of applying this research design in this sample is that it is not appropriate when the two groups being compared are very different already during the pre-acquisition period. As suggested by the findings in table 1, acquired and foreign firms are very similar with respect to their workforce composition. Therefore, to analyze changes in labor market outcomes following the foreign acquisition, I start by comparing acquired firms with other foreign-owned firms, as these are a better counterfactual than domestic firms. The important issue is to establish what would have happened to the firm had it not been acquired by foreigners. By using this group it is less likely that estimates are biased due to the selection.

Column (3) in tables 2 and 3 present the results of estimating equation (3.2) using foreign firms as control group. Following the acquisition, there are no significant changes

\footnotetext{
${ }^{28}$ Region and sector dummies are identified because there are switchers in these categories. However, empirical findings do not depend upon their inclusion.
} 
in the educational composition of the workforce in acquired domestic firms ${ }^{29}$. The only significant change is for the group of low educated workers in manufacturing, whose share falls by 1 percentage point following the acquisition. Table A5 in the Appendix shows that there is no evidence of significant changes following the acquisition in the size of the firms in manufacturing. Therefore, this decrease in the share of low educated workers is reflecting a decrease in the number of low educated workers. In non-manufacturing the number of employees increases by 25 percent and 27 percent, by the second and third year following the acquisition and, therefore, the number of low educated workers must increase accordingly ${ }^{30}$. To check the robustness of the results relative to the firms included in the control group, I estimate the same model including all the domestic and foreign firms in the sample. The results are presented in column (4) of table $2^{31}$. In sum, if foreigners choose to enter a market by acquiring an existent domestic firm, they may look for a firm where they need to make adjustments in the workforce composition or they may target a firm whose workforce composition is close to the desired level. My findings show that foreigners choose this second option since there is no significant adjustment in workforce composition following the acquisition. This seems a reasonable strategy in the presence of important employment protection in the Portuguese labor market (see Blanchard and Portugal, 2001).

\section{Wages in Foreign Firms}

To analyze the differences in the wage structure for the three education groups, I estimate hourly wages per employee as a function of several firm and worker characteristics, including

\footnotetext{
${ }^{29}$ Although not reported, these results are robust to the inclusion of the domestic acquisitions of foreign firms in the sample.

${ }^{30}$ Specification (3.2) is restrictive as it estimates an average effect following the acquisition, and restricts the impact to be zero in the years before the acquisition. I allowed for a more flexible specification where the acquisition can affect the workforce composition up to four years before and after the acquisition year (see Jacobson et al., 1993, for a similar methodology). For manufacturing I find that, 3 years before the acquisition the proportion of low educated workers starts decresing and the proportions of medium and high increasing. Specially in the third year following the acquisition there is evidence of quantitatively important changes. In non-manufacturing, the share of low educated workers also has a negative trend that is accompanied by an increase in the share of the medium educated. These changes start three years before the acquisition and, again, are not statistically different from zero.

${ }^{31}$ For computational reasons the coefficients in this model were not restricted.
} 
a foreign ownership variable:

$$
w_{k j t}=\beta_{k} f_{o r}+Z_{j t} \lambda_{k}+X_{k j t} \gamma_{k}+\alpha_{k t}+\alpha_{k r}+\alpha_{k s}+\epsilon_{k j t}
$$

$w$ stands for logarithm of real hourly wages per employee of education group $k$ of firm $j$ at time $t . X_{j t k}$ is a vector of worker level characteristics within each education group $k$ including the average age of the workers in the group, the average potential experience of the workers ${ }^{32}$, the average tenure on the firm and the proportion of females in the group. Squared terms for the age, experience and tenure variables were also included. The vector $Z_{j t}$ of firm characteristics includes size and age of the firm. The rationale for including the size of the firm on the wage equation is that foreign firms are, on average, larger, and some theories argue that larger firms pay more, either because efficiency wage theory is more effective when there is higher probability of long term relations, or because it is a compensating differential (a more dependable production process increases the cost of shirking). Finally, $\alpha_{k t}$ controls for economy wide shocks that affect one education group similarly across all firms. Differences due to regional location are captured by $\alpha_{k r}$ and differences due to sector composition are captured by $\alpha_{k s}$.

Table 4 reports the results of estimating equation (4.1) by weighted least squares to control for heteroskedasticity since the data is aggregated by education groups within the firm. Without controlling for differences in other characteristics, foreign firms pay $28 \%$ higher wages for the low educated, $19 \%$ for the medium educated and $47 \%$ for the high educated in manufacturing. Controlling for sector, region, size and age of the firm (column (2)) accounts for almost 50 percent of these differences. However, the differences between foreign and domestic firms remain quantitatively important and statistically significant for all the education groups. Adding worker characteristics in column (3) does not imply substantial changes $^{33}$. The foreign wage premium is higher for those workers with more than six years of

\footnotetext{
${ }^{32}$ Computed as age - years of schooling - six.

${ }^{33} \mathrm{I}$ find that for manufacturing sectors, larger and younger firms pay higher wages. Wages also increase with the average age of the workforce and the number of years of experience in the firm. Firm size, measured by total employment, is important for explaining wage differences in manufacturing (Feliciano and Lipsey, 1999). Large firms pay higher wages and because foreign firms are more than three times larger than domestic firms, the wage differential would have been 20 percent higher, not accounting for this characteristic.
} 
schooling. The findings for non-manufacturing in table 5 are somewhat similar. In column (1) foreigners pay wages $14 \%$ higher for low educated, $41 \%$ higher for the medium educated and $33 \%$ higher for the high educated. Controlling for firm characteristics implies a substantial decrease in the coefficients. Differences across firms in the characteristics of the medium educated account for part of the wage difference. However, after controlling for firm and worker characteristics I still find a wage differential of $8 \%$ for the low educated, $16 \%$ for the medium educated and of $11 \%$ for the high educated ${ }^{34}$. In sum, the results suggest that controlling for observable firm and worker characteristics explains part of the wage differential but fails to explain fully the foreign wage premium. At least part of these differences can reflect differences in the wage premiums of foreign firms across sectors of activity. Evidence in Table A6 in the Appendix shows that even within 2-digit sector of activity the cross-section differences between foreign and domestic firms remain statistically significant in several sectors.

\subsection{The Sample of Foreign Acquisitions}

In this subsection I use the sample of foreign acquisitions to control for those firm unobservable characteristics correlated with higher wages and also with the foreign ownership. The model estimated is the following:

$$
w_{k j t}=\eta_{k j}+\beta_{k} \text { for }_{j t}+Z_{j t} \lambda_{k}+X_{k j t} \gamma_{k}+\alpha_{k t}+\alpha_{k r}+\alpha_{k s}+\epsilon_{k j t}
$$

where all the notation is as above.

The results of estimating equation (4.2), including the firm fixed effects, by weighted least squares are presented in columns (4) and (5) of table 4 for manufacturing and in table 5 for non-manufacturing. In manufacturing, low, medium and high educated workers have increases in wages following the acquisition of $3 \%, 5 \%$ and $13 \%$, respectively. These values are substantially smaller than the ones reported in the cross section. Therefore, part of the

\footnotetext{
${ }^{34}$ For non-manufacturing, wages are higher in firms with more than 100 workers and where the workforce has more experience in the firm. Contrary to manufacturing, worker characteristics like age and tenure on the firm are important in explaining wage differences. Controlling for the age of the firm has a small effect on the wage differentials of non-manufacturing ( 3 percent increase) and no effect in manufacturing.
} 
cross section differences that we observe in the data are correlated with firm unobserved characteristics and, therefore, cannot be attributed to the foreign ownership itself. To test the robustness of the results, in column (5) I include all the domestic and foreign firms in the control group. I still find that wage increases following the acquisition are substantially smaller than the cross sectional estimates. The findings for non-manufacturing are reported in table 5. Wages for the low educated increase by $5 \%$ following the acquisition while the wages for the other groups remain unchanged. Including the domestic firms in the control group leads to an increase in wages of the medium educated by $4 \%$ while the wages of the high educated decrease in $4 \%$.

The observed increase in average wages within education groups following an acquisition could be the result of a decrease in the number of low productivity workers in the firm or it could be the result of an increase in the average productivity per worker. The findings in the previous section show that there is no substantial change in the educational composition of the workforce following a foreign acquisition. Assuming that firms are not replacing low ability workers by high ability workers within educational groups, my findings are more supportive of the argument that average productivity increases following an acquisition. To test whether increases in wages are driven by increases in productivity I include as explanatory variable a proxy for the firm aggregate productivity. The best available measure in my data to measure productivity is the average sales per employee. This measure is likely to be plagged by measurement error, since it does not include intermediate goods. My assumption is that the firm fixed effect atenuates this problem. The empirical results show that, although firms acquired by foreigners have increases in average sales per employee, the increase is uncorrelated with the foreign ownership in the wage equation ${ }^{35}$. In the presence of imperfect labor markets, foreigners might pay higher wages to workers with similar characteristics for several reasons. For example, if foreigners incur higher search costs they may pay more to workers in order to discourage turnover. If foreign firms offer more training, have less power with unions or are more likely to adhere to minimum wages,

\footnotetext{
${ }^{35}$ Results available upon request. The magnitude of the difference between foreign and domestic firms remains identical to the one reported in columns (4) and (5) of tables 4 and 5.
} 
they may also pay higher wages.

Finally, I tested for the possibility that the increases in wages are the result of the acquisition itself rather than a result of the foreign acquisition by including in the sample the group of domestic acquisitions of foreign firms. If all the firms that are acquired have improvements in productivity and, therefore, higher wages, we would expect that including this group of firms would reduce the increases in wages following the foreign ownership. I find that, after including these firms in the analysis, the wage differentials associated with foreign ownership are very similar to those reported in tables 4 and 5 . Therefore, the results suggest that wage increases are not driven by acquisitions but by the foreign ownership itself ${ }^{36}$.

\section{Conclusion}

Cross sectional evidence shows that foreign firms have a more educated workforce and pay higher wages than domestic firms. These results do not necessarily imply that foreign direct investment translates into higher demand for educated workers or higher wages, however, since foreign investment may be guided by unobservable firm characteristics correlated with the demand for educated workers or wages. Using unique firm-level data for Portugal, I seek to isolate the effect of foreign direct investment on the demand for educated workers and wages by observing labor demand and wages of different education groups before and after the foreign acquisition. Existing empirical evidence for European countries is scarce and, apart from evidence for the United Kingdom, not much is known about the impact of foreign acquisitions on labor markets. Portugal is an interesting case, as in the late 1980s and 1990s there was a permissive legal framework for the operation of foreign firms that translated into generous amounts of FDI.

My three main findings are the following. First, I show that foreign firms have a more educated workforce and pay higher wages for all education groups even after accounting for sector and regional composition, as well as other firm and worker level characteristics usually

\footnotetext{
${ }^{36}$ Unfortunatly, with this data I cannot identify the group of acquisitions of domestic firms made by national investors. If acquisitions lead to increases in wages, my estimates for the effect of foreign ownership on wages are over estimated.
} 
not accounted for due to lack of data. Second, I find evidence of an important selection effect as foreigners "cherry pick" domestic firms. Moreover, these firms are already very similar to the group of existing foreign firms and, following the foreign acquisition, there are no significant changes in the workforce educational composition. My third finding, related to the first and second, is that heterogeneity at the firm level is very important for explaining differences in the labor market outcomes between foreign and domestic firms. In fact, there are no significant changes in the workforce composition following a foreign acquisition and, while wages increase for most of the education groups, these changes are smaller than the cross-sectional estimates. 


\section{References}

[1] Aitken, B. and Harrison, A..1999. " Do domestic firms benefit from direct foreign investment?". American Economic Review, vol 89, p. 605-618.

[2] Aitken, B., Harrison A. and Lipsey, R.. 1996. "Wages and foreign ownership: a comparative study of Mexico, Venezuela and the United States". Journal of International Economics, 40 p. 345-371.

[3] Blanchard, O. and Portugal, P.. 2001. "What Hides Behind an Unemployment Rate: Comparing Portuguese and U.S. Labor Markets". American Economic Review, vol 91-1 p. $187-207$.

[4] Blanchflower D., Oswald A. and Sanfey, P. 1996. "Wages, Profits and Rent-Sharing". Quarterly Journal of Economics, February, vol.CXI (1), pp. 227-252.

[5] Brown, C. and Medoff, J..1988. "The impact of firm acquisition on labor" in A.J. Auerbach(ed.) Corporate Take-overs: Causes and consequences. University of Chicago Press: London and Chicago: p. 9-25.

[6] Caves, R. 1996. "Multinational enterprise and economic analysis". Cambridge University Press, Cambridge.

[7] Conyon, M. ,Girma, S., Thompson and Wright, P. 2002. "The productivity and wage effects of foreign acquisition in the United Kingdom". The Journal of Industrial Economics.

[8] Dimelis, S. and Louri, H. 2001. "Foreign direct investment and efficiency benefits: a conditional quantile analysis." CEPR DP \#2868.

[9] Feliciano, Z., and R. Lipsey. 1999. "Foreign ownership and wages in the United States". NBER WP \#6923.

[10] Girma, S. and Görg, H. 2001. "Blessing or curse? Domestic plants survival and employment prospects after foreign acquisition". CEPR DP \#2994.

[11] Girma, S. Greenaway, D. and Wakelin, K. 1999. "Wages, productivity and foreign ownership in UK manufacturing". University of Nottingham research paper 99/14.

[12] Haskel, J., Pereira, S. and Slaughter, M. 2002. "Does inward foreign direct investment boost the productivity of domestic firms?". NBER WP \#8724.

[13] Hamermesh, D. 1999. "The art of labormetrics". NBER WP \#6927.

[14] Jacobson, L, LaLonde, R. and Sullivan, D.. 1993. "Earnings losses of displaced workers". American Economic Review, vol 83, p. 685-709.

[15] Lichtenberg, F. and Seigel D.. 1992. "Takeovers and corporate overhead" in Corporate takeovers and productivity" F. Lichtenberg, ed., Cambridge, Massachusetts: The MIT press, p. $45-67$. 
[16] Lipsey, R. and Sjoholm, F., 2002. "Foreign firms and Indonesian manufacturing wages: an analysis with panel data". NBER working paper \# 9417.

[17] Lipsey, R. and Sjoholm, F., 2003. "Foreign direct investment, education and wages in Indonesian manufacturing". Journal of Development Economics. forthcoming.

[18] Mata, J. and Portugal, P. 1999. "Closure and divesture by foreign entrants: the impact of entry and post-entry strategies". Strategic Management Journal (2000) 21:549-562.

[19] Mata, J. and Portugal, P. 2001. "The survival of new domestic and foreign owned firms". Strategic Management Journal (2002) 23:323-343.

[20] Mata, J. and Portugal, P. 2002. "Patterns of entry, post-entry growth and survival: a comparison between domestic and foreign firms. WP 4-02 Banco de Portugal.

[21] McGuckin, R. and Nguyen. 2001. "The impact of ownership changes on labor: a view from labor markets". International Journal of Industrial Organization, vol 19 p. 739-762.

[22] Meyer, B. 1994 "Natural and quasi-experiments in economics". NBER TWP \#170. 
Table 1:

Average differences in workforce composition, employment and wages between acquired, domestic and foreign firms

\begin{tabular}{|c|c|c|c|c|c|}
\hline \multicolumn{6}{|c|}{ A. Manufacturing } \\
\hline & \multirow{2}{*}{$\begin{array}{r}\text { Foreign vs } \\
\text { Domestic }\end{array}$} & \multicolumn{2}{|c|}{ Acquisitions vs Domestic } & \multicolumn{2}{|c|}{ Acquisitions vs Foreign } \\
\hline & & Before & After & Before & After \\
\hline & $(1)$ & $(2)$ & (3) & $(4)$ & $(5)$ \\
\hline \multirow[t]{2}{*}{$\%$ Low Educated Workers } & -0.09 & -0.08 & -0.10 & 0.01 & -0.02 \\
\hline & $(0.01)$ & $(0.02)$ & $(0.02)$ & $(0.02)$ & $(0.02)$ \\
\hline \multirow[t]{2}{*}{$\%$ Medium Educated Workers } & 0.07 & 0.08 & 0.08 & 0.01 & 0.02 \\
\hline & $(0.00)$ & $(0.02)$ & $(0.02)$ & $(0.01)$ & $(0.01)$ \\
\hline \multirow[t]{2}{*}{$\%$ High Educated Workers } & 0.03 & 0.02 & 0.03 & 0.00 & 0.00 \\
\hline & $(0.00)$ & $(0.01)$ & $(0.01)$ & $(0.05)$ & $(0.04)$ \\
\hline \multirow[t]{2}{*}{ Employment } & 3.54 & 1.97 & 2.04 & 0.96 & 1.02 \\
\hline & $(0.24)$ & $(0.25)$ & $(0.25)$ & $(0.14)$ & $(0.14)$ \\
\hline \multirow[t]{2}{*}{ Av. Wage } & 0.30 & 0.26 & 0.26 & -0.03 & 0.01 \\
\hline & $(0.01)$ & $(0.05)$ & $(0.04)$ & $(0.04)$ & $(0.04)$ \\
\hline \multirow[t]{2}{*}{ Wage Low Educated Workers } & 0.24 & 0.18 & 0.18 & -0.04 & -0.01 \\
\hline & $(0.01)$ & $(0.05)$ & $(0.04)$ & $(0.04)$ & $(0.04)$ \\
\hline \multirow[t]{2}{*}{ Wage Medium Educated Workers } & 0.24 & 0.24 & 0.24 & 0.03 & 0.05 \\
\hline & $(0.01)$ & $(0.05)$ & $(0.04)$ & $(0.05)$ & $(0.06)$ \\
\hline \multirow[t]{2}{*}{ Wage High Educated Workers } & 0.46 & 0.43 & 0.50 & -0.04 & 0.11 \\
\hline & $(0.01)$ & $(0.08)$ & $(0.05)$ & $(0.04)$ & $(0.04)$ \\
\hline \multicolumn{6}{|c|}{ B. Non-Manufacturing } \\
\hline & \multirow{2}{*}{$\begin{array}{r}\text { Foreign vs } \\
\text { Domestic }\end{array}$} & \multicolumn{2}{|c|}{ Acquisitions vs Domestic } & \multicolumn{2}{|c|}{ Acquisitions vs Foreigr } \\
\hline & & Before & After & Before & After \\
\hline & $(1)$ & $(2)$ & (3) & $(4)$ & $(5)$ \\
\hline \multirow[t]{2}{*}{ \% Low Educated Workers } & -0.25 & -0.21 & -0.24 & 0.02 & 0.02 \\
\hline & $(0.01)$ & $(0.04)$ & $(0.04)$ & $(0.03)$ & $(0.03)$ \\
\hline \multirow[t]{2}{*}{ \% Medium Educated Workers } & 0.13 & 0.18 & 0.17 & 0.03 & 0.04 \\
\hline & $(0.01)$ & $(0.03)$ & $(0.03)$ & $(0.03)$ & $(0.03)$ \\
\hline \multirow[t]{2}{*}{$\%$ High Educated Workers } & 0.12 & 0.05 & 0.07 & -0.04 & -0.05 \\
\hline & $(0.02)$ & $(0.02)$ & $(0.02)$ & $(0.02)$ & $(0.02)$ \\
\hline \multirow[t]{2}{*}{ Employment } & 2.27 & 1.89 & 1.82 & 1.44 & 1.49 \\
\hline & $(0.15)$ & $(0.62)$ & $(0.44)$ & $(0.74)$ & $(0.77)$ \\
\hline \multirow[t]{2}{*}{ Av. Wage } & 0.55 & 0.41 & 0.45 & -0.09 & -0.09 \\
\hline & $(0.02)$ & $(0.06)$ & $(0.06)$ & $(0.05)$ & $(0.06)$ \\
\hline \multirow[t]{2}{*}{ Wage Low Educated Workers } & 0.39 & 0.33 & 0.39 & -0.02 & 0.01 \\
\hline & $(0.02)$ & $(0.07)$ & $(0.06)$ & $(0.06)$ & $(0.05)$ \\
\hline \multirow[t]{2}{*}{ Wage Medium Educated Workers } & 0.47 & 0.33 & 0.34 & -0.10 & -0.10 \\
\hline & $(0.01)$ & $(0.06)$ & $(0.06)$ & $(0.05)$ & $(0.05)$ \\
\hline \multirow[t]{2}{*}{ Wage High Educated Workers } & 0.48 & 0.49 & 0.42 & 0.04 & -0.04 \\
\hline & $(0.02)$ & $(0.08)$ & $(0.10)$ & $(0.07)$ & $(0.10)$ \\
\hline
\end{tabular}

Source: "Quadros de Pessoal"

Notes: Wage refers to log of real hourly wage per employee. Standard Errors in parenthesis. All the statistics are computed relatively to the two-digit sector means. "Low educated" includes workers with up to 6 years of schooling, "Medium Educated" includes workers with high school and technical courses and " High Educated" includes workers with bachelor and college degrees. "Before" and "After" refer to two years before and one year after the acquisition year, respectively. Wage statistics are not weighted. In columns (1), (2) and (3) the hypothesis of a negative differential for the share of low educated workers and a positive differential for the other two groups, relatively to domestic firms cannot be rejected. It is also not rejected the test of a positive wage differential for all the education groups. In columns (4) and (5) the hypothesis that differences between acquired and foreign firms are zero for the workforce composition and wage differentials are is never rejected. 
Table 2:

Differences in Workforce Composition Between Foreign and Domestic Firms

Manufacturing

\begin{tabular}{|c|c|c|c|c|}
\hline & $(1)$ & $(2)$ & $(3)$ & (4) \\
\hline & \multicolumn{4}{|c|}{ Panel A. Low Educated Workers } \\
\hline \multirow{2}{*}{ Foreign Ownership } & -0.151 & -0.075 & -0.011 & -0.027 \\
\hline & {$[0.004]^{* * *}$} & {$[0.004] * * *$} & {$[0.007]$} & {$[0.007]^{* * *}$} \\
\hline Adj-R square & 0.04 & 0.25 & 0.68 & 0.69 \\
\hline \multirow[t]{2}{*}{ Observations } & 21,249 & 21,249 & 1,345 & 21,249 \\
\hline & \multicolumn{4}{|c|}{ Panel B. Medium Educated Workers } \\
\hline \multirow[t]{2}{*}{ Foreign Ownership } & 0.115 & 0.054 & 0.005 & 0.016 \\
\hline & {$[0.004]^{* * *}$} & {$[0.003] * * *$} & {$[0.006]$} & {$[0.006]^{* * *}$} \\
\hline Adj-R square & 0.04 & 0.33 & 0.76 & 0.79 \\
\hline \multirow[t]{2}{*}{ Observations } & 21,249 & 21,249 & 1,345 & 21,249 \\
\hline & \multicolumn{4}{|c|}{ Panel C. High Educated Workers } \\
\hline \multirow[t]{2}{*}{ Foreign Ownership } & 0.037 & 0.021 & 0.007 & 0.01 \\
\hline & {$[0.002]^{* * *}$} & {$[0.002] * * *$} & [0.004] & {$[0.004]^{* * *}$} \\
\hline Adj-R square & 0.02 & 0.14 & 0.52 & 0.53 \\
\hline Observations & 21,249 & 21,249 & 1,345 & 21,249 \\
\hline Sector, Region and Time & $\mathrm{N}$ & Y & Y & $\mathrm{Y}$ \\
\hline Cohort and Size Firm & $\mathrm{N}$ & $\mathrm{Y}$ & Y & $\mathrm{Y}$ \\
\hline Firm Fixed Effects & $\mathrm{N}$ & $\mathrm{N}$ & Y & $\mathrm{Y}$ \\
\hline Control Group & - & - & $\mathrm{F}$ & F\&D \\
\hline
\end{tabular}

Note: Standard errors in brackets. * significant at 10\%; ** significant at 5\%; *** significant at $1 \%$. Dependent variable: the proportion of each education group in total workforce. "Low educated" includes workers with up to 6 years of schooling, "Medium Educated" includes workers with high school and technical courses and " High Educated" includes workers with bachelor and college degrees.

Specifications (3) and (4) include firm fixed effects. In specification (3) the control group includes only foreign owned firms and in specification (4) it includes domestic and foreign firms. I restricted the effect of the foreign ownership to sum up to zero for the 3 equations (low, medium and high). 
Table 3:

Differences in Workforce Composition Between Foreign and Domestic Firms Non-Manufacturing

\begin{tabular}{|c|c|c|c|c|}
\hline & (1) & (2) & (3) & (4) \\
\hline & \multicolumn{4}{|c|}{ Panel A. Low Educated Workers } \\
\hline \multirow[t]{2}{*}{ Foreign Ownership } & -0.334 & -0.224 & -0.008 & 0.001 \\
\hline & {$[0.009] * * *$} & {$[0.008] * * *$} & {$[0.008]$} & {$[0.009]$} \\
\hline Adj-R square & 0.14 & 0.42 & 0.89 & 0.89 \\
\hline \multirow[t]{2}{*}{ Observations } & 8,344 & 8,344 & 967 & 8,344 \\
\hline & \multicolumn{4}{|c|}{ Panel B. Medium Educated Workers } \\
\hline \multirow[t]{2}{*}{ Foreign Ownership } & 0.197 & 0.114 & 0.012 & -0.011 \\
\hline & {$[0.007]^{* * *}$} & {$[0.007]^{* * *}$} & {$[0.009]$} & {$[0.009]$} \\
\hline Adj-R square & 0.08 & 0.35 & 0.87 & 0.86 \\
\hline \multirow[t]{2}{*}{ Observations } & 8,344 & 8,344 & 967 & 8,344 \\
\hline & \multicolumn{4}{|c|}{ Panel C. High Educated Workers } \\
\hline \multirow[t]{2}{*}{ Foreign Ownership } & 0.137 & 0.111 & -0.004 & 0.011 \\
\hline & {$[0.004]^{* * *}$} & {$[0.004]^{* * *}$} & {$[0.008]$} & {$[0.005]^{* *}$} \\
\hline Adj-R square & 0.14 & 0.32 & 0.85 & 0.86 \\
\hline Observations & 8,344 & 8,344 & 967 & 8,344 \\
\hline Sector, Region and Time & $\mathrm{N}$ & Y & $\mathrm{Y}$ & $\mathrm{Y}$ \\
\hline Cohort and Size Firm & $\mathrm{N}$ & $Y$ & $\mathrm{Y}$ & $\mathrm{Y}$ \\
\hline Firm Fixed Effects & $\mathrm{N}$ & $\mathrm{N}$ & $\mathrm{Y}$ & $\mathrm{Y}$ \\
\hline Control Group & - & - & $\mathrm{F}$ & F\&D \\
\hline
\end{tabular}

Note: Standard errors in brackets. * significant at $10 \%$;* significant at $5 \%$; *** significant at $1 \%$. Dependent variable: the proportion of each education group in total workforce. "Low educated" includes workers with up to 6 years of schooling, "Medium Educated" includes workers with high school and technical courses and " High Educated" includes workers with bachelor and college degrees. Specifications (3) and (4) include firm fixed effects. In specification (3) the control group includes only foreign owned firms and in specification (4) it includes domestic and foreign firms. I restricted the effect of the foreign ownership to sum up to zero for the 3 equations (low, medium and high). 
Table 4:

Wage Differentials Between Foreign and Domestic Firms

Manufacturing

\begin{tabular}{|c|c|c|c|c|c|}
\hline & $(1)$ & $(2)$ & (3) & (4) & (5) \\
\hline & \multicolumn{5}{|c|}{ Panel A. Low Educated Workers } \\
\hline \multirow[t]{2}{*}{ Foreign Ownership } & 0.28 & 0.12 & 0.14 & 0.03 & 0.04 \\
\hline & {$[0.04]^{* * *}$} & {$[0.02]^{* * *}$} & {$[0.02]^{* * *}$} & {$[0.02]^{*}$} & {$[0.01]^{* * *}$} \\
\hline Adj-R square & 0.09 & 0.56 & 0.61 & 0.89 & 0.83 \\
\hline \multirow[t]{2}{*}{ Observations } & 21,099 & 21,099 & 20,969 & 1,314 & 20,969 \\
\hline & \multicolumn{5}{|c|}{ Panel B. Medium Educated Workers } \\
\hline \multirow[t]{2}{*}{ Foreign Ownership } & 0.19 & 0.11 & 0.12 & 0.05 & 0.08 \\
\hline & {$[0.07]^{* * *}$} & {$[0.03]^{* * *}$} & {$[0.02]^{* * *}$} & {$[0.02]^{* * *}$} & {$[0.01]^{* * *}$} \\
\hline Adj-R square & 0.05 & 0.46 & 0.58 & 0.93 & 0.86 \\
\hline \multirow[t]{2}{*}{ Observations } & 19,919 & 19,919 & 19,748 & 1,306 & 19,748 \\
\hline & \multicolumn{5}{|c|}{ Panel C. High Educated Workers } \\
\hline \multirow[t]{2}{*}{ Foreign Ownership } & 0.47 & 0.2 & 0.2 & 0.13 & 0.08 \\
\hline & {$[0.05]^{* * *}$} & {$[0.04]^{* * *}$} & {$[0.04]^{* * *}$} & {$[0.02]^{* * *}$} & {$[0.02] * * *$} \\
\hline Adj-R square & 0.16 & 0.48 & 0.56 & 0.81 & 0.86 \\
\hline Observations & 12,292 & 12,292 & 12,075 & 1,076 & 12,075 \\
\hline Sector, Region and Time & $\mathrm{N}$ & $\mathrm{Y}$ & Y & $\mathrm{Y}$ & Y \\
\hline Cohort and Size Firm & $\mathrm{N}$ & $\mathrm{Y}$ & $\mathrm{Y}$ & $\mathrm{Y}$ & Y \\
\hline Worker Characteristics & $\mathrm{N}$ & $\mathrm{N}$ & Y & $\mathrm{Y}$ & Y \\
\hline Firm Fixed Effects & $\mathrm{N}$ & $\mathrm{N}$ & $\mathrm{N}$ & Y & Y \\
\hline Control Group & - & - & - & $\mathrm{F}$ & F\&D \\
\hline
\end{tabular}

Note: Standard errors in brackets. * significant at 10\%; ** significant at 5\%; *** significant at $1 \%$. Dependent variable: log of hourly wages per employee in each educational group. "Low educated" includes workers with up to 6 years of schooling, "Medium Educated" includes workers with high school and technical courses and "High Educated" includes workers with bachelor and college degrees. Specifications (3) and (4) include firm fixed effects. In specification (3) the control group includes only foreign owned firms and in specification (4) it includes domestic and foreign firms. Worker characteristics includes average age of the group, average age squared, average tenure of the group, average tenure squared, average experience of the group, average experience squared and proportion of females in the group. 
Table 5:

Wage Differentials Between Foreign and Domestic Firms

Non-Manufacturing

\begin{tabular}{|c|c|c|c|c|c|}
\hline & $(1)$ & $(2)$ & $(3)$ & (4) & $(5)$ \\
\hline & \multicolumn{5}{|c|}{ Panel A. Low Educated Workers } \\
\hline \multirow[t]{2}{*}{ Foreign Ownership } & 0.14 & 0.09 & 0.08 & 0.05 & 0.06 \\
\hline & [0.09] & {$[0.03]^{* * *}$} & {$[0.03]^{* * *}$} & {$[0.02]^{* *}$} & {$[0.02] * * *$} \\
\hline Adj-R square & 0.03 & 0.49 & 0.55 & 0.94 & 0.82 \\
\hline \multirow[t]{2}{*}{ Observations } & 8,249 & 8,249 & 8,187 & 901 & 8,187 \\
\hline & \multicolumn{5}{|c|}{ Panel B. Medium Educated Workers } \\
\hline \multirow[t]{2}{*}{ Foreign Ownership } & 0.41 & 0.23 & 0.16 & -0.01 & 0.04 \\
\hline & {$[0.10]^{* * *}$} & {$[0.03]^{* * *}$} & {$[0.03]^{* * *}$} & {$[0.02]$} & {$[0.01] * * *$} \\
\hline Adj-R square & 0.18 & 0.66 & 0.72 & 0.93 & 0.91 \\
\hline \multirow[t]{2}{*}{ Observations } & 8,187 & 8,187 & 8,127 & 944 & 8,127 \\
\hline & \multicolumn{5}{|c|}{ Panel C. High Educated Workers } \\
\hline \multirow[t]{2}{*}{ Foreign Ownership } & 0.33 & 0.12 & 0.11 & 0 & -0.04 \\
\hline & {$[0.06]^{* * *}$} & {$[0.06]^{* *}$} & {$[0.05]^{* *}$} & [0.03] & {$[0.02]^{* *}$} \\
\hline Adj-R square & 0.13 & 0.44 & 0.53 & 0.84 & 0.85 \\
\hline Observations & 5,602 & 5,602 & 5,516 & 912 & 5,516 \\
\hline Sector, Region and Time & $\mathrm{N}$ & $\mathrm{Y}$ & $\mathrm{Y}$ & Y & Y \\
\hline Cohort and Size Firm & $\mathrm{N}$ & Y & Y & Y & Y \\
\hline Worker Characteristics & $\mathrm{N}$ & $\mathrm{N}$ & $\mathrm{Y}$ & Y & Y \\
\hline Firm Fixed Effects & $\mathrm{N}$ & $\mathrm{N}$ & $\mathrm{N}$ & Y & Y \\
\hline Control Group & - & - & - & F & F\&D \\
\hline
\end{tabular}

Note: Standard errors in brackets. * significant at 10\%; ** significant at 5\%; *** significant at $1 \%$. Dependent variable: $\log$ of hourly wages per employee in each educational group. "Low educated" includes workers with up to 6 years of schooling, "Medium Educated" includes workers with high school and technical courses and " High Educated" includes workers with bachelor and college degrees. Specifications (3) and (4) include firm fixed effects. In specification (3) the control group includes only foreign owned firms and in specification (4) it includes domestic and foreign firms. Worker characteristics includes average age of the group, average age squared, average tenure of the group, average tenure squared, average experience of the group, average experience squared and proportion of females in the group. 
Table A1: Characterization of the Panel by ownership type

\begin{tabular}{|c|c|c|c|}
\hline & $\begin{array}{c}\text { Domestic } \\
\text { firms }\end{array}$ & $\begin{array}{c}\text { Foreign } \\
\text { firms }\end{array}$ & Acquisitions \\
\hline \multicolumn{4}{|l|}{ 1.1 Region } \\
\hline North & $46 \%$ & $20 \%$ & $29 \%$ \\
\hline Center & $20 \%$ & $9 \%$ & $10 \%$ \\
\hline Lisbon Area & $31 \%$ & $66 \%$ & $59 \%$ \\
\hline Alentejo & $2 \%$ & $1 \%$ & $2 \%$ \\
\hline Algarve & $2 \%$ & $4 \%$ & $0 \%$ \\
\hline \multicolumn{4}{|l|}{ 1.2 Sector } \\
\hline D. Manufacturing & $63 \%$ & $55 \%$ & $52 \%$ \\
\hline DA. Food products, beverages and tabacco & $7 \%$ & $6 \%$ & $8 \%$ \\
\hline DB. Textiles and textile products & $20 \%$ & $11 \%$ & $16 \%$ \\
\hline DC. Leather and leather products & $5 \%$ & $2 \%$ & $4 \%$ \\
\hline DD. Wood and wood products & $3 \%$ & $2 \%$ & $2 \%$ \\
\hline DE. Pulp, paper and paper products & $3 \%$ & $2 \%$ & $3 \%$ \\
\hline DG. Chemicals and chemical products & $1 \%$ & $9 \%$ & $4 \%$ \\
\hline DH. Rubber and plastic products & $2 \%$ & $1 \%$ & $3 \%$ \\
\hline DI. Other non-metallic mineral products & $6 \%$ & $4 \%$ & $3 \%$ \\
\hline DJ. Basic metals and fabricated metal products & $6 \%$ & $4 \%$ & $4 \%$ \\
\hline DK. Machinary and equipment n.e.c. & $4 \%$ & $5 \%$ & $2 \%$ \\
\hline DL. Electrical and optical equipment & $1 \%$ & $7 \%$ & $3 \%$ \\
\hline DM. Transport equipment & $2 \%$ & $3 \%$ & $4 \%$ \\
\hline DN. Miscellaneous manufacturing n.e.c & $3 \%$ & $2 \%$ & $2 \%$ \\
\hline E. Electricity, gas and water supply & $0 \%$ & $1 \%$ & $0 \%$ \\
\hline F. Construction & $10 \%$ & $3 \%$ & $3 \%$ \\
\hline G. Wholesale and retail trade & $16 \%$ & $22 \%$ & $22 \%$ \\
\hline \multicolumn{4}{|l|}{ Repair motor vehicles and personal goods } \\
\hline H. Hotels and restaurants & $4 \%$ & $6 \%$ & $3 \%$ \\
\hline I. Transport, storage and communication & $4 \%$ & $4 \%$ & $6 \%$ \\
\hline J. Finantial Intermediation & $1 \%$ & $4 \%$ & $5 \%$ \\
\hline K. Real estate, renting and business activities & $3 \%$ & $7 \%$ & $8 \%$ \\
\hline \multicolumn{4}{|l|}{ 1.3 Size } \\
\hline \multicolumn{4}{|c|}{ A. Manufacturing } \\
\hline $30-49$ & $27 \%$ & $7 \%$ & $2 \%$ \\
\hline $50-99$ & $41 \%$ & $23 \%$ & $22 \%$ \\
\hline $100-499$ & $29 \%$ & $52 \%$ & $66 \%$ \\
\hline$>500$ & $3 \%$ & $18 \%$ & $10 \%$ \\
\hline \multicolumn{4}{|c|}{ B. Non-manufacturing } \\
\hline $30-49$ & $31 \%$ & $13 \%$ & $16 \%$ \\
\hline $50-99$ & $40 \%$ & $25 \%$ & $23 \%$ \\
\hline $100-499$ & $25 \%$ & $55 \%$ & $54 \%$ \\
\hline$>500$ & $3 \%$ & $8 \%$ & $7 \%$ \\
\hline
\end{tabular}

Source: "Quadros de Pessoal"

Notes: Statistics are computed in year 1995. Size of the firm is the average number of employees in 1995. 
Table A1 - Characterization of the Panel (Continued)

\begin{tabular}{|c|c|c|c|}
\hline & $\begin{array}{c}\text { Domestic } \\
\text { firms }\end{array}$ & $\begin{array}{c}\text { Foreign } \\
\text { firms }\end{array}$ & Acquisitions \\
\hline \multicolumn{4}{|c|}{ 1.4 Age of the firm } \\
\hline \multicolumn{4}{|c|}{ A. Manufacturing } \\
\hline$<5$ & $2 \%$ & $2 \%$ & $8 \%$ \\
\hline $5-15$ & $33 \%$ & $29 \%$ & $34 \%$ \\
\hline$>15$ & $65 \%$ & $69 \%$ & $58 \%$ \\
\hline \multicolumn{4}{|c|}{ B. Non-manufacturing } \\
\hline$<5$ & $3 \%$ & $3 \%$ & $7 \%$ \\
\hline $5-15$ & $23 \%$ & $35 \%$ & $33 \%$ \\
\hline$>15$ & $74 \%$ & $63 \%$ & $60 \%$ \\
\hline \multicolumn{4}{|c|}{1.5 Percentage foreign capital } \\
\hline \multicolumn{4}{|c|}{ A. Manufacturing } \\
\hline $10 \%-50 \%$ & - & $12 \%$ & $15 \%$ \\
\hline $50 \%-99 \%$ & - & $50 \%$ & $25 \%$ \\
\hline $100 \%$ & - & $37 \%$ & $60 \%$ \\
\hline \multicolumn{4}{|c|}{ B. Non-manufacturing } \\
\hline $10 \%-50 \%$ & - & $2 \%$ & $18 \%$ \\
\hline $50 \%-99 \%$ & - & $43 \%$ & $22 \%$ \\
\hline $100 \%$ & - & $55 \%$ & $59 \%$ \\
\hline \multicolumn{4}{|c|}{ 1.6 Firms in the Top 5 highest paid sectors } \\
\hline \multicolumn{4}{|c|}{ A. Manufacturing } \\
\hline Low educated & $8 \%$ & $24 \%$ & $12 \%$ \\
\hline High educated & $8 \%$ & $23 \%$ & $15 \%$ \\
\hline \multicolumn{4}{|c|}{ B. Non-manufacturing } \\
\hline Low educated & $6 \%$ & $15 \%$ & $19 \%$ \\
\hline High educated & $4 \%$ & $8 \%$ & $11 \%$ \\
\hline
\end{tabular}

Source: "Quadros de Pessoal"

Notes: Statistics are computed in year 1995. The percentage of foreign capital is the average foreign ownership during the year. The highest paid sectors for low educated workers are chemicals, electricity, paper products, electrical equipment and machinery. The highest paid sectors for high educated workers are chemicals, electrical equipment, basic metals and transport eq. The highest paid sectors for low and high educated workers are real estate, finantial intermediation and transports. 
Table A2: Sample Means of Employment, Workforce Composition and Wages for Domestic Firms

\begin{tabular}{ccc}
\hline \hline & Manufacturing & Non-manufacturing \\
\hline \% Low Educated Workers & 0.81 & 0.62 \\
& $(0.17)$ & $(0.25)$ \\
\% Medium Educated Workers & 0.14 & 0.31 \\
& $(0.12)$ & $(0.20)$ \\
\% High Educated Workers & 0.03 & 0.05 \\
& $(0.05)$ & $(0.09)$ \\
Employment & 117 & 111 \\
& $(164)$ & $(164)$ \\
Av. Wage & 1.39 & 1.64 \\
& $(0.31)$ & $(0.45)$ \\
& 1.33 & 1.55 \\
Wage Low Educated Workers & $(0.28)$ & $(0.45)$ \\
& 1.59 & 1.70 \\
Wage Medium Educated Workers & $(0.37)$ & $(0.42)$ \\
& 2.15 & 2.21 \\
Wage High Educated Workers & $(0.50)$ & $(0.53)$ \\
\hline
\end{tabular}

Note: Standard Errors in parenthesis. "Low educated" includes workers with up to 6 years of schooling, "Medium Educated" includes workers with high school and technical courses and " High Educated" includes workers with bachelor and college degrees. Wage refers to log of real hourly wage per employee. 0.81 in the first column means that the average share of low educated workers in manufacturing is $81 \%$. 
Table A3 :

Heterogeneity in the Workforce Composition of Domestic Firms

\begin{tabular}{lcc}
\hline \hline & $\begin{array}{c}\text { Proportion of } \\
\text { High Educated }\end{array}$ & Coeff. Var. \\
\hline D. Manufacturing & & \\
DA. Food products, beverages and tabacco & 0.03 & 169 \\
DB. Textiles and textile products & 0.01 & 309 \\
DC. Leather and leather products & 0.01 & 238 \\
DD. Wood and wood products & 0.02 & 187 \\
DE. Pulp, paper and paper products & 0.05 & 183 \\
DG. Chemicals and chemical products & 0.09 & 88 \\
DH. Rubber and plastic products & 0.04 & 152 \\
DI. Other non-metallic mineral products & 0.02 & 184 \\
DJ. Basic metals and fabricated metal products & 0.03 & 190 \\
DK. Machinary and equipment n.e.c. & 0.04 & 120 \\
DL. Electrical and optical equipment & 0.05 & 82 \\
DM. Transport equipment & 0.03 & 90 \\
DN. Miscellaneous manufacturing n.e.c & 0.02 & 256 \\
F. Construction & 0.04 & 138 \\
G. Wholesale and retail trade & 0.04 & 153 \\
Repair motor vehicles and personal goods & & \\
H. Hotels and restaurants & 0.02 & 144 \\
I. Transport, storage and communication & 0.03 & 170 \\
J. Finantial Intermediation & 0.19 & 86 \\
K. Real estate, renting and business activities & 0.12 & 156 \\
\hline
\end{tabular}

Notes: Proportion of high educated is the average proportion of high educated workers in domestic firms and coefficient of variation is the mean divided by the standard deviation times 100 . 
Table A4: Differences in Workforce Composition

Between Foreign and Domestic Firms, by Sector of Activity

\begin{tabular}{|c|c|c|c|}
\hline & Low & Medium & High \\
\hline \multicolumn{4}{|l|}{ D. Manufacturing } \\
\hline \multirow[t]{2}{*}{ DA. Food products, beverages and tabacco } & -0.147 & 0.112 & 0.035 \\
\hline & {$[0.012]^{* * *}$} & {$[0.010]^{* * *}$} & {$[0.005]^{* * *}$} \\
\hline \multirow[t]{2}{*}{ DB. Textiles and textile products } & -0.037 & 0.029 & 0.008 \\
\hline & {$[0.007]^{* * *}$} & {$[0.006] * * *$} & {$[0.003]^{* * *}$} \\
\hline \multirow[t]{2}{*}{ DC. Leather and leather products } & -0.021 & 0.027 & -0.006 \\
\hline & {$[0.011]^{* *}$} & {$[0.010]^{* * *}$} & {$[0.003]^{*}$} \\
\hline \multirow[t]{2}{*}{ DD. Wood and wood products } & -0.034 & 0.026 & 0.008 \\
\hline & {$[0.018]^{*}$} & {$[0.015]^{*}$} & {$[0.006]$} \\
\hline \multirow{2}{*}{ DE. Pulp, paper and paper products } & -0.061 & 0.056 & 0.005 \\
\hline & {$[0.032]^{*}$} & {$[0.025]^{* *}$} & {$[0.014]$} \\
\hline \multirow[t]{2}{*}{ DG. Chemicals and chemical products } & -0.16 & 0.1 & 0.06 \\
\hline & {$[0.017]^{* * *}$} & {$[0.014] * * *$} & {$[0.007]^{* * *}$} \\
\hline \multirow[t]{2}{*}{ DH. Rubber and plastic products } & -0.089 & 0.063 & 0.026 \\
\hline & {$[0.023]^{* * *}$} & {$[0.020] * * *$} & {$[0.011]^{* *}$} \\
\hline \multirow[t]{2}{*}{ DI. Other non-metallic mineral products } & -0.181 & 0.143 & 0.037 \\
\hline & {$[0.012]^{* * *}$} & {$[0.010] * * *$} & {$[0.006]^{* * *}$} \\
\hline \multirow[t]{2}{*}{ DJ. Basic metals and fabricated metal products } & 0.017 & -0.016 & -0.001 \\
\hline & {$[0.017]$} & {$[0.014]$} & {$[0.007]$} \\
\hline \multirow[t]{2}{*}{ DK. Machinary and equipment n.e.c. } & 0.002 & -0.019 & 0.017 \\
\hline & {$[0.020]$} & {$[0.018]$} & {$[0.007]^{* *}$} \\
\hline \multirow[t]{2}{*}{ DL. Electrical and optical equipment } & -0.018 & 0.004 & 0.014 \\
\hline & {$[0.024]$} & {$[0.020]$} & {$[0.010]$} \\
\hline \multirow[t]{2}{*}{ DM. Transport equipment } & -0.147 & 0.105 & 0.042 \\
\hline & {$[0.018]^{* * *}$} & {$[0.016] * * *$} & {$[0.005]^{* * *}$} \\
\hline \multirow[t]{2}{*}{ DN. Miscellaneous manufacturing n.e.c } & -0.045 & 0.019 & 0.026 \\
\hline & {$[0.017]^{* * *}$} & {$[0.015]$} & {$[0.007]^{* * *}$} \\
\hline \multirow[t]{2}{*}{ F. Construction } & -0.108 & 0.063 & 0.046 \\
\hline & {$[0.018]^{* * *}$} & {$[0.015]^{* * *}$} & {$[0.008]^{* * *}$} \\
\hline G. Wholesale and retail trade & -0.281 & 0.152 & 0.129 \\
\hline Repair motor vehicles and personal goods & {$[0.010] * * *$} & {$[0.009]^{* * *}$} & {$[0.004]^{* * *}$} \\
\hline \multirow[t]{2}{*}{ H. Hotels and restaurants } & -0.074 & 0.058 & 0.017 \\
\hline & {$[0.017]^{* * *}$} & {$[0.015]^{* * *}$} & {$[0.005]^{* * *}$} \\
\hline \multirow[t]{2}{*}{ I. Transport, storage and communication } & -0.403 & 0.329 & 0.074 \\
\hline & {$[0.026]^{* * *}$} & {$[0.023] * * *$} & {$[0.006]^{* * *}$} \\
\hline \multirow[t]{2}{*}{ J. Finantial Intermediation } & -0.013 & -0.017 & 0.03 \\
\hline & {$[0.013]$} & {$[0.021]$} & {$[0.020]$} \\
\hline \multirow[t]{2}{*}{ K. Real estate, renting and business activities } & -0.256 & 0.06 & 0.196 \\
\hline & {$[0.029] * * *$} & {$[0.022] * * *$} & {$[0.018] * * *$} \\
\hline
\end{tabular}

Notes: Standard errors in brackets. * significant at $10 \%$; ** significant at 5\%; *** significant at $1 \%$. Standard errors are corrected for clustering at the firm level. Controls for the sector, region, year, size and age of the firm included but not reported. 
Table A5: Employment Evolution in Acquired Firms

\begin{tabular}{|c|c|c|}
\hline & Manufacturing & 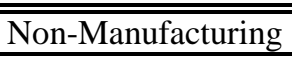 \\
\hline 4 years before & 4.4 & -37.6 \\
\hline 3 years before & $\begin{array}{c}{[20.9]} \\
18.2\end{array}$ & $\begin{array}{l}{[74.7]} \\
-35.2\end{array}$ \\
\hline 2 years before & $\begin{array}{c}{[16.4]} \\
-3.3\end{array}$ & $\begin{array}{c}{[56.6]} \\
-17.9 \\
{[424]}\end{array}$ \\
\hline 1 year before & $\begin{array}{c}-4.2 \\
{[12.6]}\end{array}$ & [31.5] \\
\hline 1 year after & $\begin{array}{c}-1.7 \\
{[12.5]}\end{array}$ & $\begin{array}{c}35.0 \\
{[24.7]}\end{array}$ \\
\hline 2 years after & $\begin{array}{l}-11.9 \\
{[13.5]}\end{array}$ & $\begin{array}{c}69.1 \\
{[26.0]^{* * *}}\end{array}$ \\
\hline 3 years after & $\begin{array}{l}-14.6 \\
{[15.4]}\end{array}$ & $\begin{array}{c}75.8 \\
{[27.6]^{* * *}}\end{array}$ \\
\hline 4 years after & $\begin{array}{c}-22.5 \\
{[17.9]}\end{array}$ & - \\
\hline Adj-R square & 0.93 & 0.99 \\
\hline Observations & 437 & 302 \\
\hline
\end{tabular}

Notes: Standard errors in brackets. * significant at 10\%; ** significant at 5\%; *** significant at $1 \%$. Firm effects included; Year of the acquisition is the omited category. Average size of the firm is 223 employees in manufacturing and 273 in non-manufacturing. 
Table A6: Differences in Wages Between Foreign and Domestic Firms, by Sector of Activity

\begin{tabular}{|c|c|c|c|}
\hline & Low & Medium & High \\
\hline \multicolumn{4}{|l|}{ D. Manufacturing } \\
\hline \multirow[t]{2}{*}{ DA. Food products, beverages and tabacco } & 0.188 & 0.241 & 0.235 \\
\hline & {$[0.050]^{* * *}$} & {$[0.038] * * *$} & {$[0.055]^{* * *}$} \\
\hline \multirow[t]{2}{*}{ DB. Textiles and textile products } & 0.14 & 0.128 & 0.307 \\
\hline & {$[0.039] * * *$} & {$[0.046] * * *$} & {$[0.060]^{* * *}$} \\
\hline \multirow[t]{2}{*}{ DC. Leather and leather products } & 0.045 & 0.108 & 0.264 \\
\hline & {$[0.021]^{* *}$} & {$[0.048]^{* *}$} & {$[0.122]^{* *}$} \\
\hline \multirow[t]{2}{*}{ DD. Wood and wood products } & 0.015 & -0.057 & 0.145 \\
\hline & {$[0.044]$} & {$[0.054]$} & {$[0.123]$} \\
\hline \multirow[t]{2}{*}{ DE. Pulp, paper and paper products } & 0.122 & 0.055 & 0.123 \\
\hline & {$[0.050]^{* *}$} & {$[0.088]$} & {$[0.153]$} \\
\hline \multirow[t]{2}{*}{ DG. Chemicals and chemical products } & 0.154 & 0.178 & 0.122 \\
\hline & {$[0.054] * * *$} & {$[0.044] * * *$} & {$[0.043]^{* * *}$} \\
\hline \multirow[t]{2}{*}{ DH. Rubber and plastic products } & 0.026 & 0.053 & -0.04 \\
\hline & {$[0.056]$} & {$[0.072]$} & {$[0.114]$} \\
\hline \multirow[t]{2}{*}{ DI. Other non-metallic mineral products } & 0.216 & 0.13 & 0.272 \\
\hline & {$[0.041] * * *$} & {$[0.030] * * *$} & {$[0.071]^{* * *}$} \\
\hline \multirow[t]{2}{*}{ DJ. Basic metals and fabricated metal products } & 0.035 & 0.093 & 0.149 \\
\hline & {$[0.032]$} & {$[0.046]^{* *}$} & {$[0.068]^{* *}$} \\
\hline \multirow[t]{2}{*}{ DK. Machinary and equipment n.e.c. } & 0.096 & 0.13 & 0.233 \\
\hline & {$[0.046]^{* *}$} & {$[0.075]^{*}$} & {$[0.109]^{* *}$} \\
\hline \multirow[t]{2}{*}{ DL. Electrical and optical equipment } & 0.002 & 0.09 & 0.308 \\
\hline & {$[0.061]$} & {$[0.057]$} & {$[0.145]^{* *}$} \\
\hline \multirow[t]{2}{*}{ DM. Transport equipment } & 0.216 & 0.077 & 0.263 \\
\hline & {$[0.038] * * *$} & {$[0.052]$} & {$[0.065]^{* * *}$} \\
\hline \multirow{2}{*}{ DN. Miscellaneous manufacturing n.e.c } & -0.018 & 0.008 & 0.147 \\
\hline & {$[0.060]$} & {$[0.065]$} & {$[0.173]$} \\
\hline \multirow{2}{*}{ F. Construction } & 0.173 & 0.219 & 0.383 \\
\hline & {$[0.078] * *$} & {$[0.093]^{* *}$} & {$[0.129] * * *$} \\
\hline G. Wholesale and retail trade & 0.192 & 0.303 & 0.277 \\
\hline Repair motor vehicles and personal goods & {$[0.050]^{* * *}$} & {$[0.039] * * *$} & {$[0.049] * * *$} \\
\hline \multirow[t]{2}{*}{ H. Hotels and restaurants } & 0.012 & 0.13 & 0.206 \\
\hline & {$[0.041]$} & {$[0.037] * * *$} & {$[0.067]^{* * *}$} \\
\hline \multirow[t]{2}{*}{ I. Transport, storage and communication } & 0.103 & 0.145 & 0.195 \\
\hline & {$[0.065]$} & {$[0.060]^{* *}$} & {$[0.069]^{* * *}$} \\
\hline \multirow[t]{2}{*}{ J. Finantial Intermediation } & 0.142 & 0.091 & 0.059 \\
\hline & {$[0.046] * * *$} & {$[0.038]^{* *}$} & {$[0.064]$} \\
\hline \multirow[t]{2}{*}{ K. Real estate, renting and business activities } & 0.025 & 0.088 & 0.129 \\
\hline & [0.017] & {$[0.046]^{*}$} & {$[0.058]^{* *}$} \\
\hline
\end{tabular}

Note: Standard errors in brackets. * significant at $10 \% ; * *$ significant at $5 \%$; *** significant at $1 \%$. Controls for three digit sector, region, size, cohort of the firm, age (age squared) of workers, potential experience of workers (potential experience squared), tenure on the firm (tenure squared) and the proportion of females in the educational group included in the model but coefficients not reported. Regressions are weighted by the number of employees in each group. 